\title{
Deniz içi nakil hatlarında polimer esaslı CNT takviyeli kompozit boruların kullanılabilirliği
}

\author{
Usability of polymer based CNT reinforced composite pipes in marine transport lines
}

\author{
Mustafa TAŞYÜREK*1,a Şerafettin EKİNCí2,b \\ ${ }^{1}$ Selçuk Üniversitesi, Sivil Havacılık Yüksekokulu, Uçak Gövde ve Motor Bakımı Bölümü, 42003, Konya \\ ${ }^{2}$ Selçuk Üniversitesi, Teknoloji Fakültesi, Makine Mühendisliği Bölümü, 42003, Konya
}

• Geliş tarihi / Received: 13.07.2020 • Düzeltilerek geliş tarihi / Received in revised form: 13.01.2021 • Kabul tarihi / Accepted: 29.03 .2021

Öz

Bu çalışmanın amacı, karbon nano tüp (CNT) takviyeli plastik boruların deniz suyu içerisinde kullanılabilirliği ve bunun sonucunda mekanik özelliklerdeki değişimi incelemektir. Deneylerde kullanılan cam/epoksi borular, $[ \pm 55] 3$ fỉber oryantasyonuna sahip olup; filaman sarım metoduyla üretilmiştir. İkincil takviye malzemesi olarak ağırlıkça \% 1 oranında CNT kullanılmıştır. Deney numuneleri, kuru ortamın yanı sıra 2,3,4,6 ve 9 aylık reel sürelerle deniz suyu içerisinde bekletildikten sonra çekme ve sertlik testlerine tabi tutulmuşlardır. Testler, ASTM D 2290 standardına göre split disk metoduna uygun halka numuneler üzerinde gerçekleştirilmiştir. Sonuçlar, referans malzemesi cam takviyeli plastikten (CTP) elde edilen sonuçlar ile kıyaslama yapılmıştır. Elde edilen sonuçlara göre CNT’lerin kompozit yapı içerisine girmiş halde üretilmesinin delaminasyon hasarını azalttığ 1 ve bunun sonucunda da kuru ortam şartlarında \%21, uzun dönem kullanımlarda ise yaklaşık \%18 mukavemet artı̧ı sağladığı belirlenmiştir.

Anahtar kelimeler: Boru nakil hatları, Deniz suyu, Filaman sarım, Karbon nanotüp

\begin{abstract}
The aim of this study is to investigate the usability of carbon nanotube (CNT) reinforced plastic pipes in seawater and consequently the changes in mechanical properties. The glass / epoxy tubes used in the experiments have fiber orientation of $[ \pm 55] 3$ and are produced by filament winding method. $1 \%$ CNT was used as secondary reinforcing material. The test specimens were subjected to tensile and hardness tests after being kept in seawater for real periods of 2,3,4,6 and 9 months in addition to dry environment. Tests were performed on ring samples according to the split disc method based on ASTM D 2290 test standard. The results were compared with the results obtained from glass reinforced plastic (GRP). According to the results, it was found that the production of CNT reinforced composite structure reduced the delamination damage and as a result of this it provided $21 \%$ strength increase in dry environment conditions and also increased the strength in long term usage by approximately $18 \%$.
\end{abstract}

Keywords: Pipeline transmission lines, Sea water, Filament winding, Carbon nanotube

\footnotetext{
*a Mustafa TAŞYÜREK; mtasyurek@selcuk.edu.tr, Tel: (0505) 53236 23, orcid.org/0000-0001-9016-8584

${ }^{\mathrm{b}}$ orcid.org/0000-0003-0885-5903
} 


\section{Giriş}

Günümüzde elyaf takviyeli kompozit malzemelerle hayatın her noktasında çok sik karşılaşılmaktadır. Gerek akademik gerekse ticari bakımdan tercih edilen bu malzemelerin kullanımı; havacılık, otomotiv, denizcilik, nakliye, askeri ve yapısal alanlarda gittikçe artmaktadır (Ghasemi, vd., 2014). Bilim insanları tarafindan, birden çok takviye malzemesi kullanılarak kompozit oluşturmak, takviyelerin boyutlarını çeşitlendirmek, biyolojik kökenli malzemeler kullanmak, çeşitli tahmin ve analiz programlarından yararlanılarak nano boyuta indirgemek gibi farklı yöntemler araştırılmaktadır (Bellucci, vd., 2019; Bousfield, vd., 2018; Gemi, 2018; Mousavi ve Khoramishad, 2019; Prabhu, 2015). Bazı araştırmacılar çalışmalarında, CNT'lerin sıra dışı özelliklerinden ve bunların matrikse transfer edebilmelerinden dolayı, polimer matriks içerisinde takviye malzemesi kullanmaya odaklanmışlardır (Jesthi ve Nayak, 2019; Kim, vd., 2014; Mittal vd., 2015; Nayak, 2019).

CNT'ler, elyaf-matriks ara yüzey bağını kuvvetlendirmek amaciyla geleneksel elyaf takviyeli kompozitlerde ilave takviye bileşeni olarak tercih edilmeye başlanmıştır (Jin, vd., 2019; Matveeva, vd., 2019). Çünkü elyaf matriks arasındaki arayüz, sadece elyaf ve reçine arasındaki bağlantı köprüsü değil; aynı zamanda harici yükün matristen fibere iletimini sağlayan bir vasıta olarak görülmektedir (Xiao vd., 2018). Bu sebeple arayüz yapısı, özellikleri ve bağlanma modu, kompozit yapının hasar modlarını ve hasarın etkisini doğrudan etkileyen bir unsurdur. (Chen vd., 2018); CNT takviyeli kompozit oluştururken imalat aşamasının önemine değinmiş ve takviye malzemesinin matriks ile yeterli miktarda 1slatılmamasının, zayıf mekanik bağlanmaya yol açacağından bahsetmişlerdir. Burada mukavemet artırımının elde edilebilmesinin ve CNT'nin yük transferini olumlu etkileyebilmesinin yolunun, arayüz mikro yapısının iyi optimize edilerek uygun üretim şartlarının sağlanmasından geçtiği vurgulanmıştır.(Irshidat, vd., 2016) ise, bir elyaf/epoksi kirişinin güçlendirilmesinde CNT tercih etmişler ve mukavemet artışında etkili olduğunu bildirmişlerdir. Çalışmalarında, sertlik ve tokluk artışının elde edilmesinin yanı sıra kompozit hata modlarından tabaka ayrılmasını geciktirilebildiğini; bunun nedeninin ise epoksi ve elyaflar arasındaki yapışmayı artıran CNT ile zenginleştirilmiş elyaf tabakasının olduğunu vurgulamışlardır. Mekanik yük altında çalışan cam elyaf takviyeli plastiklerin yorulma ömrünü arttırmak için, matriks malzemesinin nano malzemelerle takviye edilmesinde bu arayüzey kuvvetlendirici etkiyi kullanmanın büyük bir potansiyeli vardır (Liu vd., 2018; Xiao vd., 2018). Ayrıca, CNT takviyesi yapmanın tabakalı kompozit yapılarda hasar yollarını sınırlamasından dolayı kırılma tokluğunu, tabakalar arası kayma mukavemetini arttırdığı ve delaminasyon hasarını geciktirdiği ve azalttığı da araştırmalarda belirtilmiştir (Hassan vd., 2019; Kaynan, vd., 2018).

Nanomalzemeler, belirli özellikler için tasarlanabilen ve gelişmekte olan sıra dış1 malzemeler ailesidir. Bu malzemeler, dizayn edip geliştirmek istediğimiz malzemelerin davranışlarında önemli değişiklikler meydana getirebilir. Deformasyon ve kırılma dayanımı, süneklik, sertlik, mukavemet, aşınma, yorulma, sürtünme, korozyon direnci, termal ve kimyasal stabilite ve elektriksellik gibi özellikler bunun için uygundur (Gu, vd., 2018; Kara, vd., 2019; Makowiec ve Blanchet, 2017; Rahmanian vd., 2013; Taşyürek and Tarakçioğlu, 2017a, 2017b; Zhang vd., 2019).

Dünyada ve Türkiye'de hızla gelişen nano teknolojinin önümüzdeki y1llarda birçok alan için ne kadar vazgeçilmez olduğu daha iyi anlaşılmaktadır. Özellikle Tıp, savunma, tekstil, enerji, elektronik, mekatronik ve gida gibi alanlarda nano teknoloji ile elde edilecek ürünler, insanoğlunun hayatını kolaylaştırmaktadır (Assatse, vd., 2019; Bajpai vd., 2018; Grujicic, vd., 2008; Tang, vd., 2017). Bu alanlardan birisi de denizcilik sektörüdür (Ng, vd., 2013). Ülkemizdeki lojistik hizmetleri, son ylllardaki kamu ve özel sektör altyapı yatırımlarının artması sonucu ciddi oranda gelişmiştir. Boru hatları, büyük miktarda su, içecek, petrol ve doğal gaz gibi akışkanları başka bir bölgeye nakletmedeki en ekonomik yoldur. Fakat kullanılan boru tipleri oldukça sinırlıdır. $\mathrm{Bu}$ sinırın kaldırılması veya genişletilmesi için alternatif nakil hattı oluşumlarının hayata geçirilmesi gerekmektedir. $\mathrm{Bu}$ da mevcut şartların, nano teknolojinin getirmiş olduğu avantajlarla desteklenerek bir ilerleme elde edilmesini gerekli kılmaktadır.

Denizlerdeki tuzluluk oranları \%3.1-3.8 arasında değişir. Ortalama tuzluluk değeri ise, yaklaşık olarak \%3.5 olarak kabul edilmektedir. Ortalama yoğunluk ise, su yüzeyinde $1.025 \mathrm{~g} / \mathrm{ml}$ 'dir. Normal suya göre yoğunluk farkının nedeni deniz suyunda yer alan tuz taneciklerinin kütlesinden kaynaklanmaktadır. Deniz suyundaki tuz oranı, bölgelere göre farkl1lık göstermektedir. Ülkemizin 3 tarafının denizlerle çevrili olması ve jeopolitik 
konumunun önemi sebebiyle deniz içi araştırma faaliyetleri son yıllarda oldukça artmıştır. Bu da denizde sondaj faaliyetleri, deniz seviyesi altından içme suyu nakil hatları, petrol arama faaliyetleri gibi konularda çeşitli kompozit malzemelerin tuzlu deniz suyu içerisinde kullanılabilirliğinin önemini oldukça arttırmıştır. Deniz seviyesinin alt kısımlarında, nakil hatlarında kullanılan boruların içlerinden nakledilen sıv1 veya gazların değişebilirliğinin yanı sıra, dış yüzeyler sadece saline etkili deniz suyu ile temas halinde olmaktadır. Suyun depolaması ve nakledilmesinde, termoplastik kökenli plastik malzemelerin yaygın olarak kullanıldığı bilinmektedir. Fakat deniz suyu ve okyanus suyu gibi saline etkili sular içerisinde, termoset plastiklerin bekletilmelerinin önemi, denizlerin kullanımı açısından da son yıllarda artmıştır. Çünkü, uzun dönem uygulamalarında malzemelerin nasıl davranacağını bilmek oldukça önem taşımaktadır (Tsotsis, vd., 2001). Araştırmaciların bu ve benzeri sebepler neticesinde gerçek deniz suyu içerisinde yaşlandırarak, farklı yönlerden mekanik özelliklerini araştırdıkları çalışmalara da rastlanmaktadır. (Davies, vd., 2005) deniz suyu uygulamalarda kullanılmak üzere karbon kökenli kompozit malzemeleri 1 ve 3 aylik yaşlandırma sürelerine tabi tutarak hidrostatik basınç testleri gerçekleştirmişlerdir. Çalışmalarında deniz suyuna maruz bırakma süresinin mekanik özellikleri olumsuz etkilediğini, fakat karbon takviyesinin geleneksel malzemelere kıyasla daha yüksek mekanik dayanım test sonucu gösterdiğini bildirmişlerdir.

(Öndürücü ve Muzoğlu, 2019), 2 ay süreyle deniz suyunda beklettikleri doğal lif takviyeli cam elyaf kompozit numunelerin kritik burkulma yüklerini deneysel olarak incelemişlerdir. Yaptıkları çalışmaları sonucunda deniz suyunun doğal kompozitlerin burkulma dayanımını olumsuz yönde etkilediğini bildirmişlerdir. (Deniz, vd., 2013); 3, 6 ve 9 ay sürelerde yaşlanmaya tabi tuttukları cam elyaf-epoksi tabakalı kompozitlerin darbe davranışlarını belirleyebilmek için darbe deneyleri yapmışlardır. Elde edilen sonuçlar kompozit plakaların darbe davranışı üzerine deniz suyundaki tuzun, darbe enerjisinin ve darbe ucu kütlesinin önemli etkisinin olduğunu göstermişlerdir.

$\mathrm{Bu}$ çalışmanın amacı, karbon nanotüp (CNT) ile takviye edilen cam takviyeli plastik (CTP) boruların, deniz suyunda bekletilme şartları altında mekanik özelliklerini araştırmaktır. Deniz suyunun CNT takviyeli ve CTP malzeme üzerindeki uzun süreli etkisi sonucunda, eğri ve tabakalı yapıların kullanılabilirliğinin araştırılması amaçlanmaktadır. Literatürdeki çalışmalardan farklı olarak 9 ay gibi uzun bir sürede yaşlandırmaya tabi tutulan kompozit numunelerin çekme ve sertlik gibi mekanik özellikleri araştırılarak, literatürdeki boşluk doldurulmaya çalışılmıştır. Sonuçlar göstermiştir ki; tabakalı ve eğri kompozit yapıların CNT ile ekstra olarak takviyelendirilerek multiskala hibrit bir yapının oluşturulması; ara yüzey özelliklerinin ve dolayısıyla mekanik özelliklerin geliştirilmesinde önemli katkı sağlamaktadır.

\section{Materyal ve metot}

\subsection{Malzemeler}

Nanokompozit yapı elde etmek için tercih edilen reçine bileşenleri Ciba Geigy Bisphenol A epoksi ve sertleştirici maddesidir. Bu reçine birincil olarak 1200 tex E Cam elyafi ile takviyelendirilmiştir. VWR firmasından temin edilen çok duvarlı karbon nanotüp (MWCNT) tozların bireysel olarak çekilen ham görüntüsü ve matriks ile karıştırıldıktan sonra elde edilen kompozit karışımın taramalı elektron mikroskobu (SEM) görüntüsü Şekil 1'de görülmektedir. Ayrıca CNT'lerin genel özellikleri Tablo 1'de, epoksi matriks ile cam elyafin özellikleri ise Tablo 2'de verilmiştir.

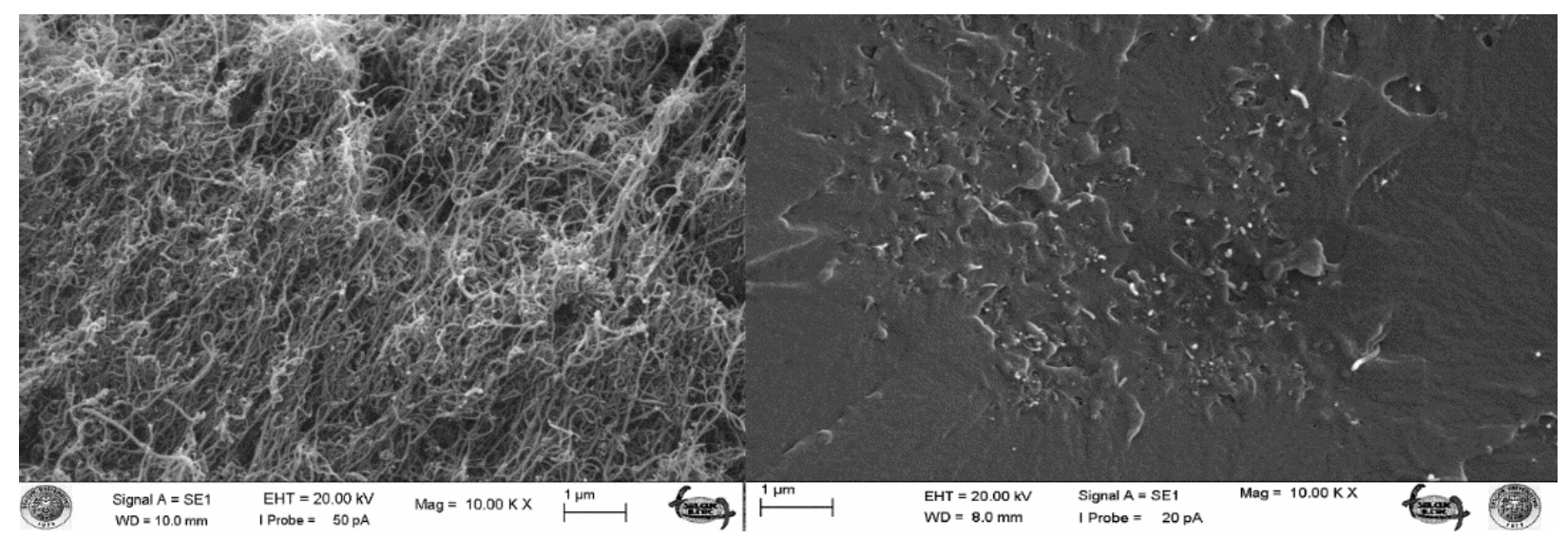

Şekil 1. Kullanılan karbon nanotüpün orijinal hali ve matriksle karıştırma sonrası homojen karışım SEM görüntüsü 
Tablo1. Karbon nanotüpün fiziksel özellikleri

\begin{tabular}{lc}
\hline \multicolumn{1}{c}{ Özellik } & Değer \\
\hline Dış Çap & $<8 \mathrm{~nm}$ \\
İç Çap & $2-5 \mathrm{~nm}$ \\
Kül Oranı (ağıllıç̧a) & $<\% 1.5$ \\
Saflık & $>\% 95$ \\
Boy & $10-30 \mu$ \\
Özgül Yüzey Alanı & $500 \mathrm{~m}^{2} / \mathrm{g}$ \\
Hacimsel Yoğunluk & $0.27 \mathrm{~g} / \mathrm{cm}^{3}$ \\
Gerçek Yoğunluk & $2.1 \mathrm{~g} / \mathrm{cm}^{3}$ \\
\hline
\end{tabular}

Tablo 2. Epoksi reçine ve cam elyafı mekanik özellikleri

\begin{tabular}{cccccc}
\hline Özellikler & $\mathbf{E}$ & $\boldsymbol{\sigma}(\mathbf{M P a})$ & $\mathbf{P}\left(\mathbf{g} / \mathbf{c m}^{\mathbf{3}}\right)$ & $\boldsymbol{\varepsilon}$ & $\boldsymbol{\mu}(\mathbf{m . P a} . \mathbf{s})$ \\
\hline E Cam Elyaf & 73 & 2400 & 2.6 & $1.5-2$ & - \\
Epoksi Reçine & 3.4 & $50-60$ & 1.2 & $4-5$ & $8000-12000$ \\
\hline
\end{tabular}

Çalışmada kullanılan deniz suyu, Doğu Akdeniz'den Antalya-Kıbris hatt1 arasından alınmıştır. Sözü edilen bölgenin deniz suyuna ait bileşen verileri şu şekildedir: Klorür $19000 \mathrm{mg} / \mathrm{l}$, Sodyum 10500 mg/l, Magnezyum 1270 mg/l, Kükürt 880 (2640 sülfat) mg/l, Kalsiyum 400 mg/l, Potasyum 380 mg/l, Bromür 65 mg/l, Karbon 28 (140 bikarbonat) mg/l, Stronisyum $13 \mathrm{mg} / \mathrm{l}$, Bor 5 mg/l (Doğanay ve Ulcay, 2007).

\subsection{Numune hazırlama}

Tüm boruların imalatında, 6 eksenli filaman sarım cihazında mandrelin dönüş hızının, elyaf taşıyıcı arabanın mandrel ekseni boyunca gidiş ve dönüş hızının, dolayısıyla elyaf sarım açısının ve boru uç kısımlarında taşıyıcı kafasının dönüşünün kontrol edildiği bilgisayar destekli bir program kullanılmıştır.

Reçinenin optimum sıcaklık aralı̆̆ oranının istenen seviyede olmasını sağlayabilmek ve elyafların yeterli miktarda 1slatılması için reçinenin orta viskoziteye sahip olduğundan dolayı 60-65 ${ }^{\circ} \mathrm{C}$ olarak seçilmiştir. Islatmanın istenilen seviyede olması için elyaf çekme hızı fazla tutulmamıştır.

CNT'lerin epoksi içerisine karıştırılması, imalat prosesinin ilk kısımlarını değiştirmiştir. İlk olarak viskozitesi ayarlanmış reçine içerisine, ağırlıkça $\% 1$ oranındaki CNT katılarak, mekanik olarak karıştırılmıştır. CNT’nin bu oranda seçilmesindeki amaç, topaklanmayı engelleyerek, takviyenin muhtemel olumlu etkisini belirleyebilmektir. Ultrasonik ses dalgalarının direk olarak karışmamış CNT ve epoksinin üzerine uygulanarak nano boyuttaki takviye malzemesinin uçuşmasını önlemek amacıyla ön karıştırma işlemi olarak seçilen mekanik karıştırma işlemi 5 dakika süreyle $250 \mathrm{~d} / \mathrm{dk}$ dönme hızında bir mekanik karıştırıcı kullanılarak gerçekleştirilmiştir. Daha sonra Bandelin HD 2200 marka ultrasonik homojenizatör kullanılarak, cihaza özgü \%65 güç seviyesinde 15 dakikalık sürede, homojen bir şekilde karıştırılmıştır (Taşyürek, 2014). Cihaz gücü ve frekansı matriks ve takviyenin özelliklerine göre iyi ayarlanmazsa ya istenen homojen dağılım ve dispersiyon elde edilememekte ya da fazla güç sebebiyle takviye üzerinde kırılma, bükülme, burkulma, boy kısalması, çap genişlemesi ve katman sayısının azalması gibi hasarlar meydana gelebilmektedir (Grishchuk ve Schledjewski, 2013). Ultrasonikasyon uygulamasında doğru yaklaşım ile uygulanan nano partikül takviyesi, topaklaşma yapmadan matriks içinde düzgün bir şekilde dağıtılabilmektedir. Bunun yanı sıra homojenizatörü uzun süre ve tam gücünde çalıştırarak karıştırma işlemini yapmak, CNT'lerin boylarında kısalmalara, kırılmalara ve tüp şeklinin bozularak avantajının kaybolmasina neden olacağından yüksek güce ayarlanmamıştır. Kullanılan CNT'lerin sertleştirici malzemeden etkilenmediği kabul edilmiştir. Elyaf rulolarından çıkarak bir araya gelen elyafların bant genişliği 12 $\mathrm{mm}$ olarak ayarlanmıştır. $600 \mathrm{~mm} / \mathrm{dk}$ hızla yapılan sarım işlemi sonucunda $72 \mathrm{~mm}$ iç çaplı ve $\pm 55^{\circ}$ sarım açılı, toplamda 6 katlı numuneler üretilmiştir. Tüm numunelerin ortalama cidar kalınlığı $2.2 \mathrm{~mm}$ olarak kabul edilmiştir.

Tüm işlemler sonunda kürleme aşamasına geçilmiştir. Kürleme işlemindeki numuneler firın içerisinde sürekli bir döner tertibatta döndürülmek suretiyle $135{ }^{\circ} \mathrm{C}$ ve müteakip $150{ }^{\circ} \mathrm{C}$ 'de 3 'er saat bekletilmiştir. Daha sonra numuneler, çekme aparatları yardımıyla mandrellerden çıkarılıp kesilerek deneylere hazır hale getirilmiştir. Tüm 
numune hazırlama işlemlerinin şematik gösteriminin yanı sıra mekanik deneyler sonrasinda SEM incelemelerinde ön fikir oluşturması ve boru kesitinde oluşan hasar mekanizmalarının değerlendirilmesi için $\pm 55^{\circ}$ sarım açısında üretilen filaman sarım kompozit boruların tabaka sayısının ve fiber oryantasyonunun anlaşılabildiği kesit görüntüsü Şekil 2'de verilmiştir.

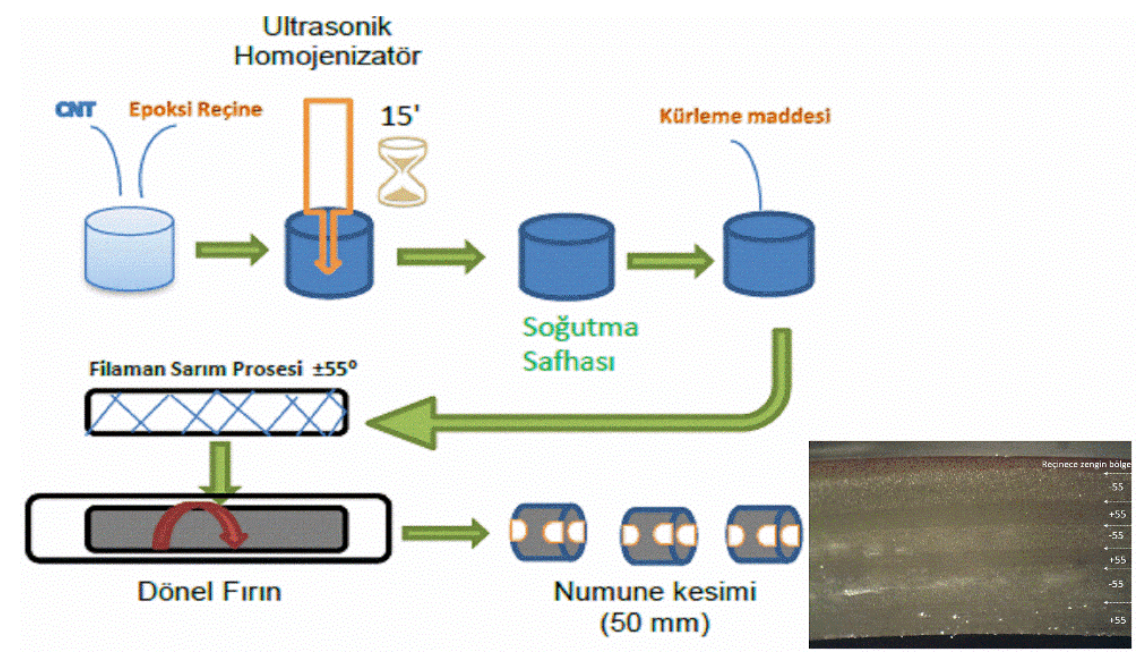

Şekil 2. Nanokompozit oluşumu, deney numunesi hazırlama prosedürünün şematik gösterimi ve elde edilen kompozit borunun cidar kalınlığına ait kesit görüntü

\subsection{Metot}

Numunelerin hazırlanması esnasında mekanik özelliklerde azalma ve numuneler arası değişim yaşanmaması için hava boşluklarının oluşmamasına ve elyaf hacim oranının sabit tutulmasına dikkat edilmiştir. Bu bağlamda ASTM D 2584 test standardına göre ateşleme kaybı testi ve ASTM D2734 test standardına göre de boşluk içeriği testleri gerçekleştirilmiştir. Boşluk içeriği denklem (1) ve denklem (2)'de görülen formüllerle deneysel olarak hesaplanmıştır.

$V=100 .(T / d-M / d) / T_{d}$
$T_{d}=100 /\left(R_{1} / D_{1}+r_{1} / d_{1}\right)$

Denklem (1)'de $T_{d}$ ve $M_{d}$ sirasiyla teorik ve pratik kompozit yoğunluğunu temsil etmektedir. Denklem (2)'de görülen $\mathrm{R}_{1}, \mathrm{D}_{1}, \mathrm{r}_{1}$ ve $\mathrm{d}_{1}$ ise sirasiyla reçine ağırlığı, reçine yoğunluğu, elyaf ağırlığı ve elyaf yoğunluğunu temsil etmektedir.

Malzemelerin statik yük altındaki davranışlarını belirlemek amacıyla, tabakalı ve eğri yapılar için uygun olan halka çekme testi uygulanmıştır. Tüm testler oda sicaklığında yapılmıştır. Halka çekme numunelerinin test edilebilmesi için ASTM D 2290 standardina uygun olarak aparat imalatı yaptırılmıştır. Çalışmada çekme testleri elektro servo motorlu dinamik test makinasında yürütülmüştür. Test aparatının ve halka çekme test numunesinin aparata bağlanmış halinin şematik görüntüsü Şekil 3'te verilmiştir.

Filaman sarım metodu ile üretilen CNT takviyeli ve CTP borulardan elde edilen numuneler, ASTM D 2290 split disk metodu ile test edilmiştir. Deniz suyunda bekletilen CTP boruların, teğetsel yöndeki malzeme özelliklerindeki muhtemel değişikliklerini belirlemek için kullanılan metotlardan birisi de halka çekme deneyidir. Test sicaklığı laboratuvar oda sicaklığı olan $23{ }^{\circ} \mathrm{C} \pm 2^{\circ}$ $C^{\prime}$ de, nem oran 1 ise $\% 50 \pm 5$ değerinde sabit tutulmuştur. Test hızı asgari $2.5 \mathrm{~mm} / \mathrm{dk}$ 'dır. Testler 3 tekerrür olacak şekilde yapılmış ve grafiklerde ortalama değerleri dikkate alınmıştır.

Test, $\quad \pm 55^{\circ}$ sarım açılı borularda gerçekleştirilmiştir. Ayrıca testin uygulanmasında kullanılan aparat, eğilme momentinin etkisi minimize edilerek dizayn edilmiştir. Dizayn esnasında, test standardında verilen aparat şeklinde önemli bir değişiklik yapılmamıştır. Bunun uygulanması için özellikle tespit pimlerinin 1s1 sertleştirilmeden geçirilmesine, boru numunesi iç çapı ile aparat yarım ay şeklindeki parçalarının dış çaplarının ölçülerinin birbirine yakın olmasına dikkat edilmiştir. Aksi halde numuneler önce eğmeye daha sonra çekmeye zorlanacaktır.

Numunelerin kırılma yüzeylerinden alınan görüntülerle gerçekleştirilen morfolojik analizler ZEISS Evo LS 10 model SEM cihazı kullanılarak 
yapılmıştır. Yüzeylere görüntüleme işlemi öncesinde, flu görüntüye ihtimal vermeyecek şekilde Cressington Sputter 108 kaplayıc cihaz ile
$40 \mathrm{~mA} / \mathrm{mbar}$ 'da 7 nm kalınlığındaki altın kaplama işlemi otomatik olarak uygulanmıştır.

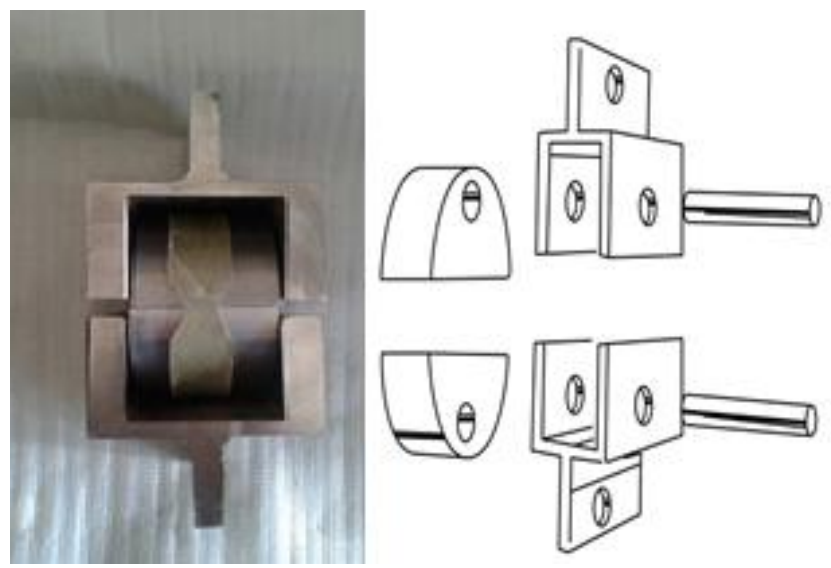

Şekil 3. Halka çekme testlerinde kullanılan Split disk (halka çekme) test aparatı ve teste hazır numuneler

\section{Araştırma sonuçları ve tartışma}

\subsection{Mekanik analiz}

Mekanik analize başlamadan önce numuneler arası sağlıklı bir karşılaştırma yapabilmek için bazı fiziksel özelliklerinin de aynı olması ya da ihmal edilebilir düzeyde birbirlerine yakın olmasının gereksinimi nedeniyle gerçekleştirilen boşluk içeriği testlerinde numunelerde yaklaşık olarak $\% 0.24$ oranında boşluk olduğu tespit edilmiştir. $\mathrm{Bu}$ durum kaliteli bir kompozit malzeme için yeterli görülerek diğer testlere devam edilmiştir. Ayrıca yakma testi sonucunda elyaf hacim oranlarının hem CTP malzeme hem de \%1 CNT takviye edilmiş nano kompozit malzeme için 0,52 olarak bulunmuştur.

Halka çekme test sonuçları Şekil 4'te görülmektedir. Burada CNT takviyeli numuneler CTP numunelere kıyasla daha üstün sonuçlar vermektedir. Ayrica numunelerin deniz suyunda bekletmesinin olumsuz bir sonucu olduğu da görülmektedir. Gerilme değerlerinde, 9 aylık bir bekletmenin sonunda \%50'den fazla bir düşüş görülmektedir. Değerlere bakıldığında; kritik sürenin 6 ay olduğu anlaşılmaktadır. 6 ay sonrasında her iki tür numunede de kayda değer azalma görülmektedir. $\mathrm{Bu}$ değer düşüşlerinin sonucu, hasar analizi ve sertlik ölçümleri ile açıklanmaktadır. Yaklaşık olarak 6 ay sonrasında numuneler, rijitliklerini kaybetmekte, bu da gerilme değerlerindeki azalma ile sonuçlanmaktadır. Kuru şartlar altında ve su içerisinde bekleme şartlarındaki tüm deney sonuçlarında, CNT takviyesi gerilme değerini yaklaşık olarak \%20 oranda arttırmaktadır. Benzer sonuçlar, rijitlikleri arttırılarak gerilme sonuçlarının azaldığının tespit edildiği betonarme bir malzemenin deney sonuçlarında da görülmüştür (Alpaslan, vd., 2015).

Deniz suyunda bekletilen numunelerin, kuru şartlardaki numunelere kıyasla rijitliklerinin azalması sonucunda tabakalar arasında matriksin yapışma özelliği zayıflamıştır. Bu da 6 tabakadan oluşturulan bir yapının çekmeye maruz kalması yerine üst üste bindirilmiş ve muhtelif yerlerinden yapıştırılmış 2'şer tabakalı yapıların çekmeye maruz bırakılması durumuna dönmüştür. Böylece, kalınlıkları azaltılmış ince cidarlı numuneler gibi davranmaya başlamışlardır. Test numunesinin inceltilmiş kısım kenarlarının ince cidarlı yapı haline dönüşmeye başlaması, çekme gerilmesinin azalmasına neden olmuştur. $\mathrm{Bu}$ durum CTP numunelerde Mod I kirılma durumu ile açıklanabilir. Fakat CNT takviyeli numuneler, ayrılmaya çalışan tabakaların arasında dikey konumda bir mekanik kilitlenme elemanı gibi davranmıştır. Böylece çekme testi esnasında, tabakaların birbirinden ayrilmasina neden olan kuvvete zit yönde bir mekanik kuvvet ortaya çıkmıştır. $\mathrm{Bu}$ da aylara göre azalan gerilme değerinin azalma oranını yavaşlatmıştır.

9 ay bekleyen numunelerin değerlerindeki düşüşler, kuru ortam şartlarında gerçekleşen testlerin değerlerinin yüzde 50'sinden daha düşük değere ulaştığından numunelerin kullanılabilirlik süresi açısından kritik eşiğin aşıldığ 1 düşünülmüştür. $\mathrm{Bu}$ sebeple daha uzun sürelerde testlerin yapılmasına gerek duyulmamıştır. 


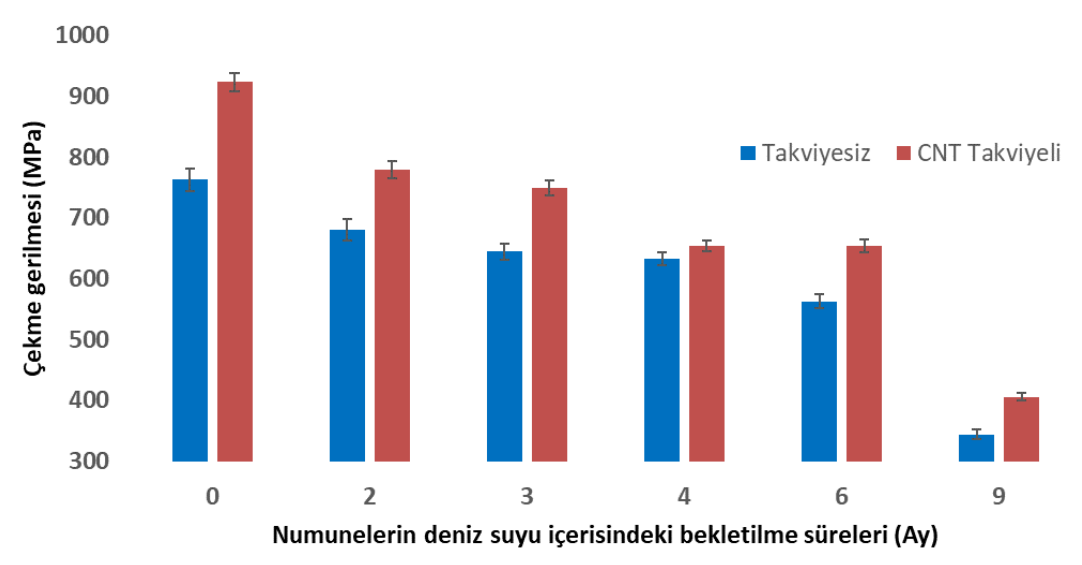

Şekil 4. Muhtelif sürelerde bekletilen numunelerin halka çekme testi sonuçları

Şekil 4'te verilen sonuçlara göre görülmektedir ki; kuru ve deniz suyu şartlarına göre CNT takviyeli numunelerin çekme gerilmesi değerleri CTP numuneninkilere kiyasla daha yüksektir. CTP numunelerin çekme mukavemetlerindeki değer düşüklüğü deniz suyunda bekletilmemiş kuru numunelerde $\% 17.40$ iken deniz suyunda bekletilen numunelerde $\% 15$ civarındadır.

Azalma yüzdeleri kuru ortamda çekme testi uygulanan CNT takviyeli numunenin değeri ile kıyaslandığında nano malzemenin bireysel üstün özelliklerini kompozit yapıya aktarabildiği daha iyi anlaşılabilmektedir. Elde edilen CNT takviyeli halka çekme numunesinin mukavemet değeri deniz suyuna maruz bırakılmamış numuneye kıyasla \%21.07'lik artı̧ gösterirken, bu değer ilk deniz suyunda bekletme ölçüm süresi olan 2. ayın sonunda \%35'i geçmiştir. Son ölçüm zamanında ise $\% 168$ gibi bir değere ulaşmıştır.

Üretim şartlarının prosedüre uygun olarak yürütüldüğünü ve sağlıklı karşılaştırma adına numuneler arası fiziki farklılıkların olmadığının ispatı olarak üretim sonrası fiziksel özelliklerin tespit edilmesi gerekmektedir. $\mathrm{Bu}$ gereksinimi karşılamak için elyafların tamamının hacimsel oranları $\% 52$ olarak tespit edilmiştir ve numuneler arası bir farklılık ölçülmemiştir. Buna ilaveten üretim şartlarının iyi olmaması nedeniyle ortaya çıkabilen hava boşluklarının varlığı da \%0.22 olarak belirlenmiştir.(Clyne ve Hull, 2019) çalışmasına göre her bir \%1'lik boşluk içeriğinin tabakalar arası kayma mukavemetini $\% 7$ oranında azalttığ 1 dikkate alınırsa üretilen numunelerdeki $\% 0.22$ 'lik boşluk içeriğinin ciddi oranda mukavemet kaybına sebep olmadığı söylenebilir.

Epoksiler genel olarak yüksek mukavemet ve sertliğe sahip malzemelerdir. Sertliklerini uzun süreli olarak koruyabilirler. Fakat deniz suyunun aşındırıcı ve yıpratıcı etkisi epoksi üzerinde baskın rol oynayabilir. Şekil 5 incelendiğinde CNT takviyeli ve CTP boru numunelerinin uzun süre reel deniz suyu ortamında bekletilmesi suretiyle elde edilen sertlik değerleri görülmektedir. Hem kuru şartlar altında hem de deniz suyu bekleme şartları altında CNT takviyeli numunelerin sertlik değerlerinde üstünlük göze çarpmaktadır. Aylara göre düşüş oranları tüm numuneler arasında benzerlik göstermektedir. Fakat CTP numunelerde 2. ve 4. Aylarda görülen düşüş daha köklü olmuştur ve çekme davranışları ile örtüşmektedir. CNT takviyesinin ise bu kararlılığı yaklaşık olarak 4. ay sonuna kadar sürdürdüğ̈u görülmektedir. Burada genel olarak CNT takviyeli numunelerin sertlik değerlerinde yaklaşık olarak \%1.1 oranında artış söz konusudur. Kritik eşik olan sürelerden birisi olan 4. ayda yapılan ölçümde ise bu oranın yaklaşı $\mathrm{k}$ olarak \%1.7 olduğu bulunmuştur.

CNT'li numunelerin üretimi esnasında CNT'lerin ilk olarak matriks malzeme ile karıştırılması ve elde edilen nanokompozit malzemenin elyaf demetleri ile tabakalı ve eğri yapının oluşturulması sonuç verilerinin artmasına katkı sağlamıştır. Öncelikle elde edilmiş olan nanokompozit matriks 1slatma suretiyle hem elyaflar arasına girdirilmiş hem de en dış tabakada yer alan elyafların dış yüzeyine yaklaşık olarak 0,4 mm'lik bir kaplama oluşturması numune dışının da sertleşmesine neden olmuştur. Zira takviyeli epoksi malzemenin mekanik özellikleri takviyesiz epoksi değerlerine göre üstünlük göstermiştir.

Burada homojen yapının oluşturulabilmesi büyük önem arz etmektedir. Homojen yap1 elde edilmediği takdirde yapılan sertlik ölçümlerinin temas noktalarının elemental yapısı farklılık göstereceği için birbirinden farklı değerler ortaya çıkacaktır. Buna karşıllık homojenizasyon sertlik testleri sonuçlarının birbirine yakın değerler vermesi sağlanarak sonucun geçerliliği arttırılmıştır. 


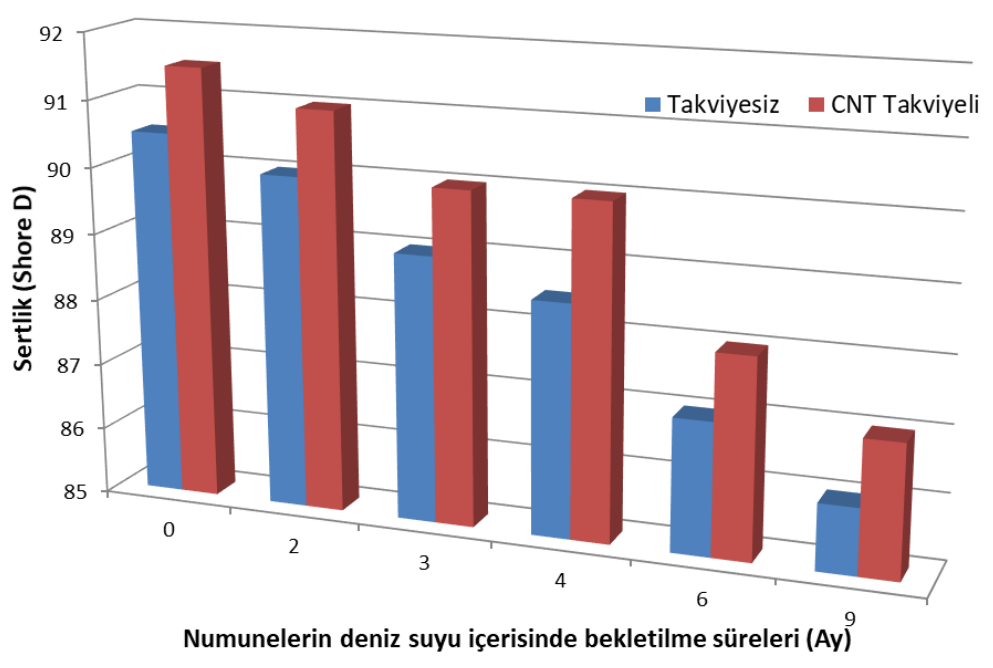

Şekil 5. Muhtelif sürelerde deniz suyu içerisinde bekletilen numunelerin Shore D sertlik değerleri

\subsection{Tabakalar arası hasar analizi}

Numunelerin deniz suyunda bekletilmesi, sertlik testlerinde ve gerilme değerlerindeki düşüşler, hasar alanının oluşmasında etken faktörlerdir. Bunlar yükselen delaminasyon alanı artıșı ile ortaya çıkmıştır. CNT takviyeli numunelerin sonuçlarına bakıldığında; kritik eşiğin yine 6 ay olduğu görülmektedir. CTP numunelerin değerlerinde ise 1 aylik bekleme ve 4 aylik bekleme, iki kritik eşiktir ve tabakalar arası alanın ciddi miktarda arttığı görülmektedir. CNT'ler tabakalar arası mukavemeti arttırma, elyafların birbirlerinden ayrılmasını geciktirme, epoksinin hızlı bir şekilde hasarlanmasını geciktirme gibi olumlu özelliklere sahiptir. Hasar alanlarındaki nano takviyeli ve takviyesiz numuneler arasındaki değişiklik, CNT'lerin tabakalı kompozitlerde kullanılmasında; tabakalar arası bağlanma elemanı gibi davranmasına yorumlanmıştır. Bu sebeple tüm bekleyen numuneler kendi aralarında aylara göre değerlendirildiğinde; CNT takviyeli numunelerin kırılma mukavemetleri yüksek olmakta ve hasara karşı daha dayanıklı olmaktadırlar.

Halka çekme testlerinin tamamı standarda uygun olarak gerçekleştirilmiş ve tüm numuneler aynı şekle ve ölçülere sahiptir. Test sonunda numuneler, inceltilmiş kısım olarak adlandırılan orta kısımlarının tamamen bertaraf olması şeklinde hasara uğramıştır. Ayrıca numunelerin çekme testi esnasındaki dikey konumuna göre çapraz şekilde delaminasyon hasarı devam etmiştir. Hasar yönlenmesinin nedeni, boruların imalat sırasında elyafların matriks içerisindeki sarım açısının derecesidir. Ayrıca delaminasyon genişliği bir veya birkaç elyaf bandı ile sınırlanmıştır.

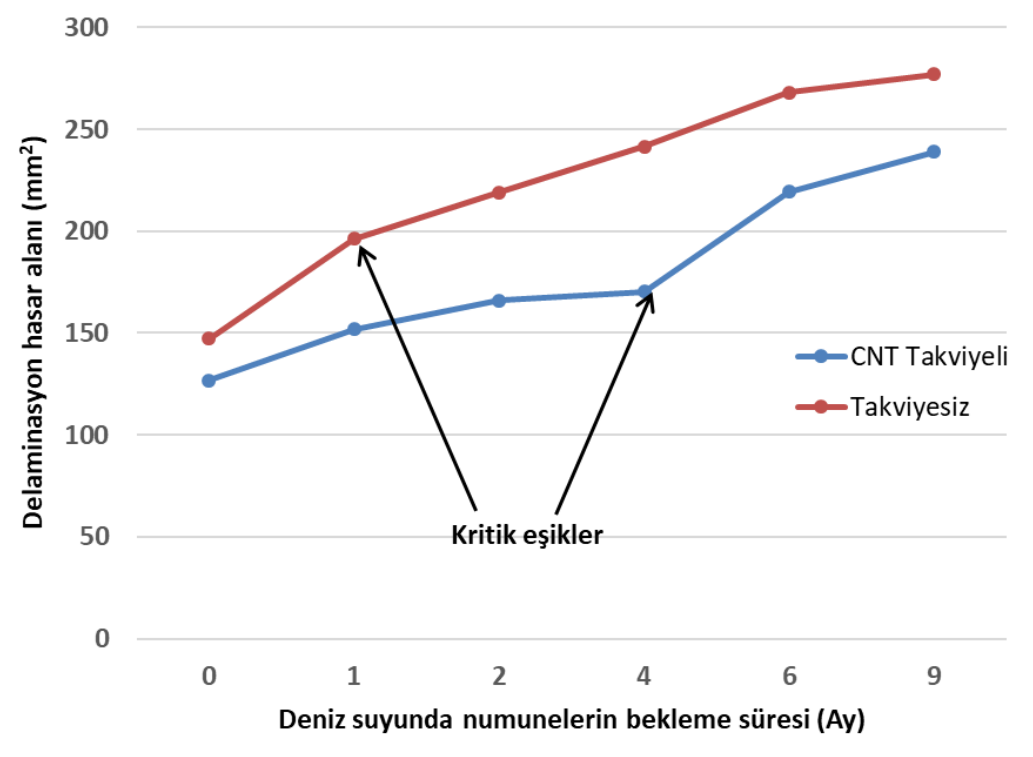

Şekil 6. Çeşitli aylarda bekletilen numunelerin halka çekme testi sonucundaki delaminasyon hasar alanları 
Şekil 7'de görüldüğü gibi hasar oluşumu CTP numunelerde kolaylıkla izlenebilmektedir. Fakat CNT takviyeli numunelerin şeffaf olmamasından dolayı inceleme yalnızca iç yüzeylerde yapılabilmiş ve alan değerlerinin hesaplanması bu kısımlardan alınan ölçülere göre yapılmıştır.

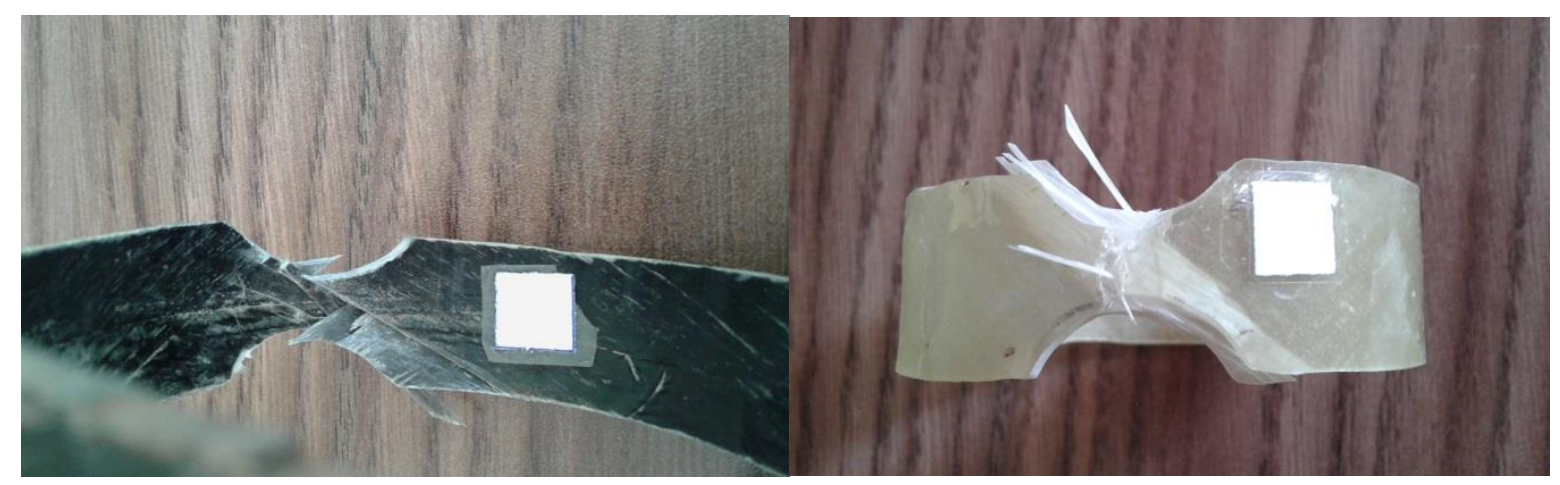

Şekil 7. CNT Takviyeli ve takviyesiz numunelerin delaminasyon hasarının karşılaştırma ve pixel sayma yöntemi ile tespit edilmesi

\subsection{Mikroyapı incelemesi}

Mikroyap1 incelemesi çekme testi sonrası numunelerin kırılma yüzeylerinden alınan SEM görüntüleri ile yapılmıştır. Şekil 8'de CTP numunelerin çekme testi SEM görüntüleri verilmiştir. Şekilde çok sayıda kırılan elyaf uçlarının yanı sıra çekme testi esnasında yerinden ayrılan elyafların bıraktığı boşluklar görülmektedir. $\mathrm{Bu}$ tür numunelerde kompozit hasarları arasında yer alan elyaf kırılması, elyaf kopmaları ve matriksten ayrılmalar sıklıkla görülmektedir. Elyafların çıkması gibi görülen hasar mekanizmalarının yaşanması elyaf-matriks arasındaki ara yüzey bağının zayıflığı ile açıklanmaktadır ve delaminasyona da neden olabilmektedir.

Gerçek şartlar altında, uzun süreli deniz suyu içerisinde bekletilen nanokompozit yapıların kusur oluşumu ve elyaf-matriks arayüzey geliştirme mekanizmalarının SEM görüntüleri, sırasıyla Şekil 9 ve Şekil 10 a-b'de verilmiştir. Şekil 9'da, yoğun delaminasyon hasarı, kırılan elyaflar ve dış yüzey mikro matris çatlakları ile oluşum yerleri görülmektedir. Kompozit hatalarından mikro matriks çatlakları, genelde reçine tabakası denilen reçine bakımından zengin bölgede oluşmaktadır. Mikro çatlakların da, çekme kuvvetinin yönünün etkisiyle elyaflara dik yönde oluştuğu görülmektedir. Cam elyaf tabakaları arasında ise düşük matriks bölgeleri sebebiyle delaminasyon hasarlarının ve fiber kırılmalarının yoğunlaştığı görülmektedir. Elyaf demetlerine dik yönde uygulanan çekme kuvveti, onları kırılmaya zorlamalarının yanı sıra matriks üzerinde de mikro çatlak oluşumuna yol açmaktadır. Bu hataların birleşimi de delaminasyon oluşumuna sebep olmaktadır. Hata bölgeleri birbirini tetiklediği için oluştukları bölgeler aynıdır. Bu sebeple fiberler dikey yönlü zorlamalara karşı koyamamakta ve tek başlarına dikey olarak kırılmaktadırlar. Özellikle matriks çatlaklarının tabaka ayrılma kısımları ile birleştiği noktalarda, matriks ciddi şekilde hasar görülmektedir. Deniz suyunda bekletilmeleri sonrasında yapılan testler sonucu tüm numunelerde bir miktar delaminasyon ve elyaf siyrilması hasarının oluştuğu görülmüştür. Bu oluşum CNT takviyeli olarak üretilen numunelerde daha az oluşmakta ve bu oluşumun da daha uzun süre deniz suyunda bekletilen numunelerin SEM incelemelerinde görülebildiği söylenebilir.

Matriks ve nano parçacıkların kompozit oluşturması sonucu, arayüzey bağını doğrudan ölçmek zordur (Lee, vd., 2014). Fakat kırılma yüzeylerinden alınan SEM görüntüleri, Şekil 10 a ve b'deki gibi yapışma durumunu iyi göstermiştir. CNT'lerin fiziksel boyutları sebebiyle sayısız parçacık olarak takviye yapıldığı durumlarda, uygun üretim şartlarının da sağlanmasına bağlı olarak, matriks fiber arayüzey yapışmaları artmaktadır. Kırılma yüzeylerinden alınan örneklerin SEM fotoğraflarından anlaşıldığı üzere; CNT'ler, elyaflara dik olarak konumlandırıldıklarından dolayı delaminasyonun azaldığ 1 görülmektedir. Bu iyileşme de kompozit hatalarının birbirini tetiklemesini olumsuz etkileyerek elyaf kırılmalarını da azaltmaktadır. Ayrıca küçük boyutlarından ve homojen dağıtılabildiklerinden dolayı, matriks içerisinde çok sayıda arayüzey oluşturarak nanokompozit bir matriks oluşumu sağlandığından; mikro matriks çatlaklarının sayısında da bir azalma yaşanmaktadır. 


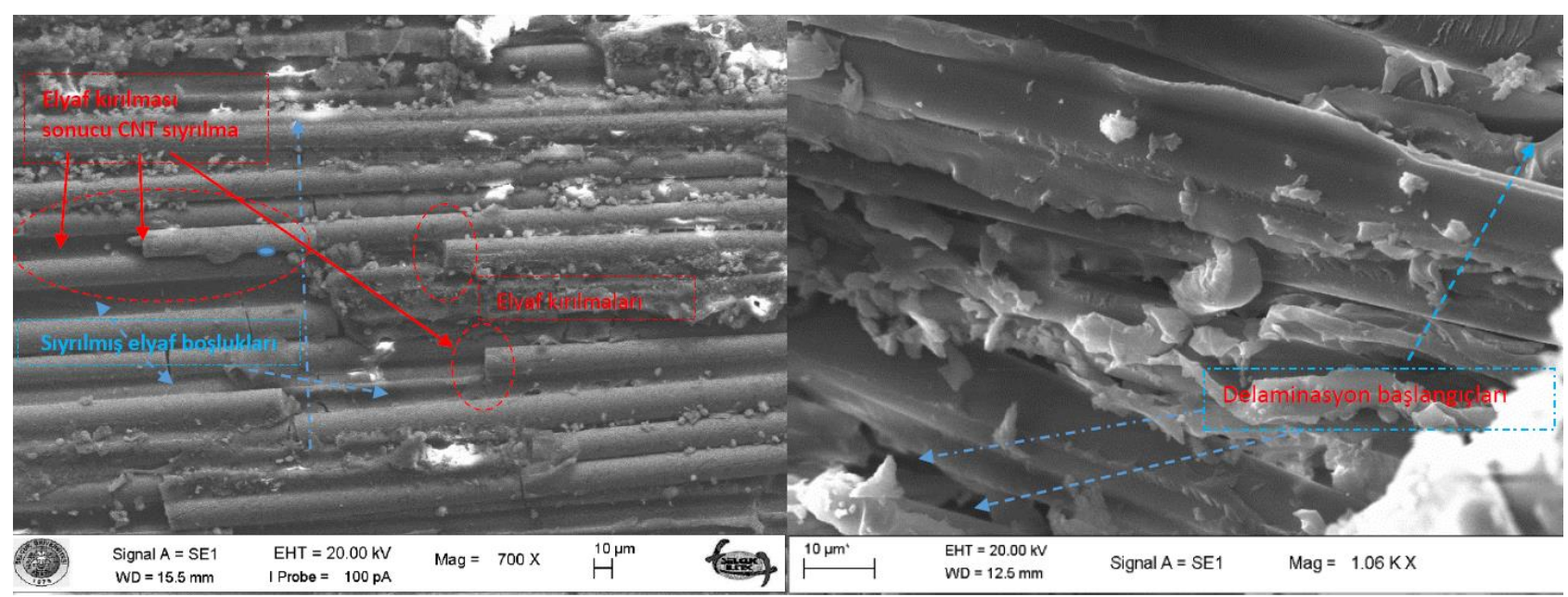

Şekil 8. Takviyesiz (CNT’siz) elyaflı plastik malzemenin halka çekme testi sonucu gerçekleşen elyaf kırılması, elyaf sıyrılmaları ve delaminasyon hasarı başlangıçlarının oluşumu

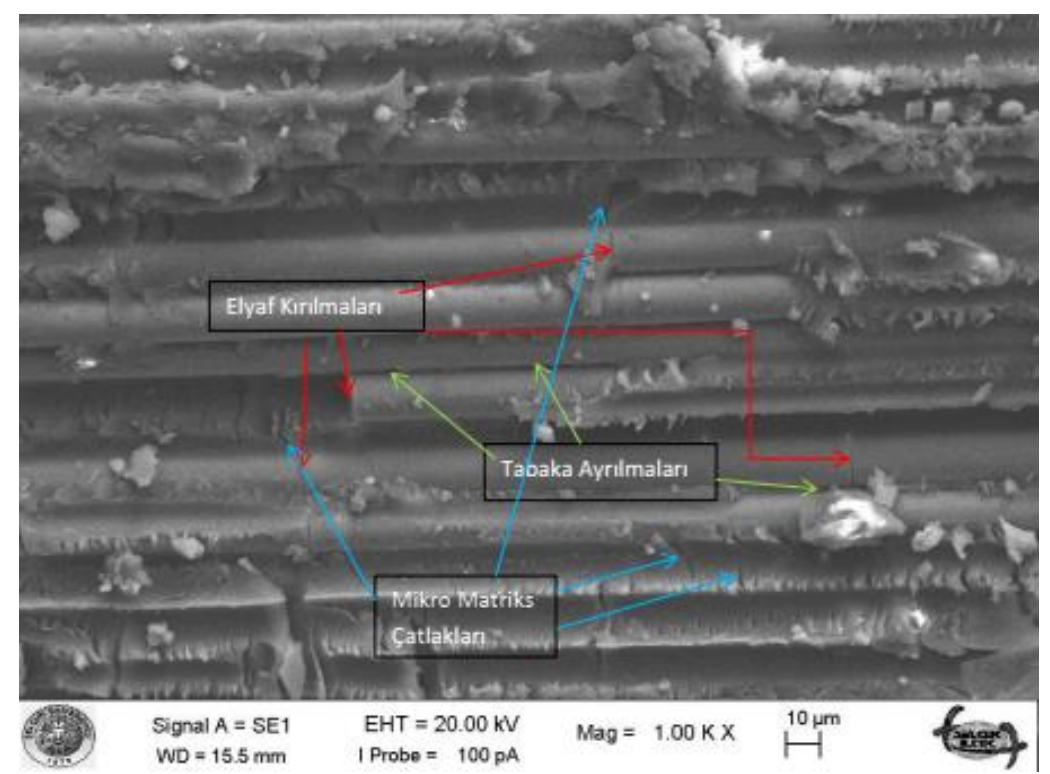

Şekil 9. Çekme testi esnasında deniz suyunda bekletilmiş CNT takviyeli CTP halka çekme numuneleri kırılma yüzeylerinde içyapı mikro çatlak ve delaminasyon oluşumu

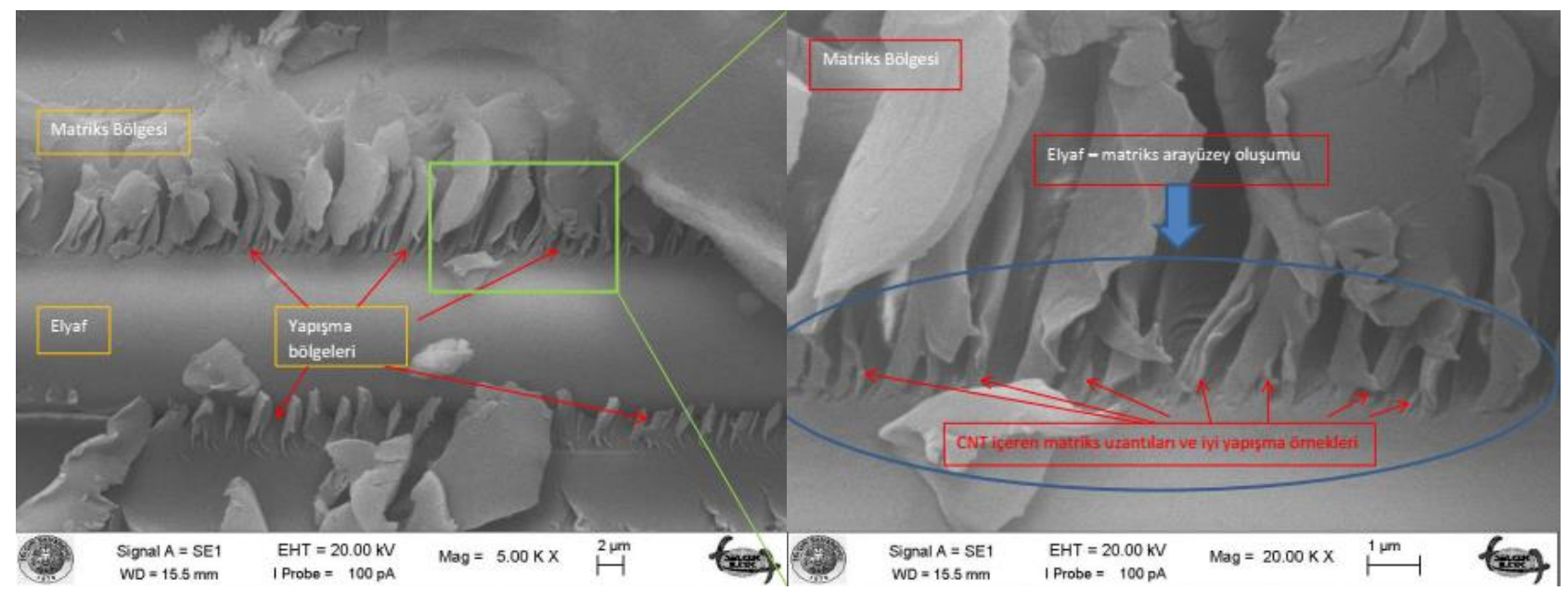

Şekil 10. CNT'lerin elyaf - matriks arasındaki arayüzeyde iyi yapışma özelliği sergilemesiyle bağlanma durumunun oluşumu ve kompozit hatalarının engellenmesi (a) $5.00 \mathrm{KX}$ büyütme (b) $20.00 \mathrm{KX}$ büyütme 


\section{Sonuçlar}

$\mathrm{Bu}$ çalışmada, ultrasonikasyon tekniği ve filaman sarım yöntemi ile homojen yapıda multi-skala CNT/epoksi/cam elyaf hibrit kompoziti üretilmiştir. Ticari olarak satılan ve endüstriyel ölçülerde olan CTP borulara alternatif olarak üretilen bu hibrit malzemeler, gerçek zamanlı olarak deniz suyuna maruz bırakılmış ve belirlenen zamanlara göre sertlik ve çekme testleri uygulanmıştır. $\mathrm{Bu}$ doğrultuda elde edilen sonuçlar ve öneriler aşağıda sunulmuştur:

- Halka çekme deneylerinde CNT takviyesinin yapılmasıyla elyaflar arasında mekanik bir bağlanma oluşturması ve elyaf matriks arayüzeyini kuvvetlendirmesinin sonucunda boru eksenine dik doğrultudaki mukavemet artmaktadır. Kuru ortam şartlarında CTP halka çekme numunelerinde $763 \mathrm{MPa}$ değer bulunurken, $\% 1$ oranında CNT takviyeli numunelerde $923 \mathrm{MPa}$ değer elde edilerek yaklaşık olarak \%21'lik bir artış sağlanmıştır.

- Su emme zamanı sonucu, her iki tür numunenin de gerilme değerlerinde azalma meydana gelmiştir. $\mathrm{Bu}$ durum, numunelerin elastikliklerindeki artış, rijitliklerindeki azalmanın bir sonucu olarak karşımıza çıkmaktadır.

- Deniz suyunda bekleme zamanının 6 ay olması, çekme karakteristiği açısından CNT'li numuneler dikkate alındığında kritik zaman değeridir. Bu zaman süresi, takviyesiz numunelere bakıldığında 2-4 ay arasına düşmektedir. 9 ay süresince bekleme sonucu gerilme değerleri $\% 50$ 'den fazla gerçekleşmiştir.

- Belirlenen kritik kullanılabilirlik süresine göre gerilme değerleri, CNT takviyesi yapılarak yaklaşık olarak \%16 civarında arttırılmıştır.

- Her iki tür malzemede de zamana göre sertlik değerlerinde düşüş meydana gelmektedir. Fakat CNT takviyeli numunelerin, rijitliklerini daha uzun süre koruyabildiği görülmektedir. $\mathrm{Bu}$ da CNT'lerin tabakalar arası mekanik kilitlenme yapmas1 sonucu, delaminasyon hasarını azaltması ve geciktirmesi ile açıklanmıştır. Delaminasyon hasarındaki dikkate değer artış, takviyesiz numunelerde ilk ay sonunda yaşanırken; takviyeli hibrit numunelerde 4 ay sonra gerçekleşmiştir.

- Yapılan çıkarımlara göre epoksi-CNT nanokompozitleri, hem kuru ortam şartlarındaki hem de çeşitli sürelerde deniz suyu etkisine maruz bırakılma şartlarındaki numuneler üzerinde, sertlik ve çekme gerilmesi açısından olumlu etki sağlayarak; mükemmel mekanik özellikler ve ömür göstererek kullanılabilirliğini ciddi miktarda geliştirmiştir.

\section{Teşekkür}

Bu çalışma Selçuk Üniversitesi Bilimsel Araştırma Projeleri Koordinatörlüğü tarafindan 14401109 numaralı proje ile desteklenmiştir. Ayrıca yazarlar makalenin inceleme ve değerlendirme aşamasında yapmış oldukları katkılardan dolayı editör ve hakemlere teşekkür etmektedir.

\section{Kaynaklar}

Alpaslan, E., Haciefendioğlu, K., Birinci, F. ve Kurt, M. (2015). Tarihi yapilarda lokal güçlendirmeye bağli lokal rijitlik artişinin yapi davranişina etkisi. 2015 3. Türkiye Deprem Mühendisliği ve Sismoloji Konferansı (3. TDMSK) İzmir.

Assatse, Y. T., Ejuh, G., Tchoffo, F. and Ndjaka, J. (2019). DFT studies of nanomaterials designed by the functionalization of modified carboxylated carbon nanotubes with biguanide derivatives for nanomedical, nonlinear and electronic applications. Chinese Journal of Physics, 58, 253-262. https://doi.org/10.1016/j.cjph.2019.01.014

Bajpai, V. K., Kamle, M., Shukla, S., Mahato, D. K., Chandra, P., Hwang, S. K. and Han, Y.K. (2018). Prospects of using nanotechnology for food preservation, safety, and security. Journal of food and drug analysis, 26(4), 1201-1214. https://doi.org/10.1016/j.jfda.2018.06.011

Bellucci, D., Salvatori, R., Anesi, A., Chiarini, L. and Cannillo, V. (2019). SBF assays, direct and indirect cell culture tests to evaluate the biological performance of bioglasses and bioglass-based composites: Three paradigmatic cases. Materials Science and Engineering: C, 96, 757-764.

https://doi.org/10.1016/j.msec.2018.12.006

Bousfield, G., Morin, S., Jacquet, N. and Richel, A. (2018). Extraction and refinement of agricultural plant fibers for composites manufacturing. Comptes Rendus Chimie, 21(9), 897-906. https://doi.org/10.1016/j.crci.2018.07.001

Chen, X., Tao, J., Yi, J., Liu, Y., Bao, R., Li, C. and You, $X$. (2018). Enhancing the strength of carbon nanotubes reinforced copper matrix composites by optimizing the interface structure and dispersion uniformity. Diamond and Related Materials, $\quad 88, \quad 74-84$. https://doi.org/10.1016/j.diamond.2018.06.026 
Clyne, T. W. and Hull, D. (2019). An introduction to composite materials. Cambridge university press.

Davies, P., Riou, L., Mazeas, F., and Warnier, P. (2005). Thermoplastic composite cylinders for underwater applications. Journal of Thermoplastic Composite Materials, 18(5), 417443. https://doi.org/10.1177/0892705705054397

Deniz, M. E., Ozdemir, O., Ozen, M. and Karakuzu, R. (2013). Failure pressure and impact response of glass-epoxy pipes exposed to seawater. Composites Part B: Engineering, 53, 355-361. https://doi.org/10.1016/j.compositesb.2013.05.0 47

Doğanay, S. ve Ulcay, Y. (2007). Farklı oranlarda takviye edilmiş cam lifi polyester kompozitlerin deniz suyu etkisi altında yorulma davranışının incelenmesi. Uludağ University Journal of The Faculty of Engineering, 12(2).

Gemi, L. (2018). Investigation of the effect of stacking sequence on low velocity impact response and damage formation in hybrid composite pipes under internal pressure. A comparative study. Composites Part B: Engineering, 153, 217-232. https://doi.org/10.1016/j.compositesb.2018.07.0 56

Ghasemi, H., Brighenti, R., Zhuang, X., Muthu, J. and Rabczuk, T. (2014). Optimization of fiber distribution in fiber reinforced composite by using NURBS functions. Computational Materials Science, 83, 463-473. https://doi.org/10.1016/j.commatsci.2013.11.03 2

Grishchuk, S. and Schledjewski, R. (2013). Mechanical dispersion methods for carbon nanotubes in aerospace composite matrix systems. In Carbon Nanotube Enhanced Aerospace Composite Materials (pp. 99-154): Springer.

Grujicic, M., Bell, W., Thompson, L., Koudela, K. and Cheeseman, B. (2008). Ballistic-protection performance of carbon-nanotube-doped polyvinyl-ester-epoxy matrix composite armor reinforced with E-glass fiber mats. Materials Science and Engineering: A, 479(1-2), 10-22. https://doi.org/10.1016/j.msea.2007.06.013

Gu, B.-E., Huang, C.-Y., Shen, T.-H. and Lee, Y.L. (2018). Effects of multiwall carbon nanotube addition on the corrosion resistance and underwater acoustic absorption properties of polyurethane coatings. Progress in Organic Coatings, 121, 226-235. https://doi.org/10.1016/j.porgcoat.2018.04.033

Hassan, E. A., Ge, D., Zhu, S., Yang, L., Zhou, J. and Yu, M. (2019). Enhancing CF/PEEK composites by $\mathrm{CF}$ decoration with polyimide and loosely- packed CNT arrays. Composites Part A: Applied Science and Manufacturing, 127, 105613. https://doi.org/10.1016/j.compositesa.2019.1056 13

Irshidat, M. R., Al-Saleh, M. H. and Almashagbeh, H. (2016). Effect of carbon nanotubes on strengthening of RC beams retrofitted with carbon fiber/epoxy composites. Materials \& Design, $\quad 89, \quad 225-234$. https://doi.org/10.1016/j.matdes.2015.09.166

Jesthi, D. K. and Nayak, R. K. (2019). Evaluation of mechanical properties and morphology of seawater aged carbon and glass fiber reinforced polymer hybrid composites. Composites Part B: Engineering, $174, \quad 106980$. https://doi.org/10.1016/j.compositesb.2019.1069 80

Jin, K., Wang, H., Tao, J. and Zhang, X. (2019). Interface strengthening mechanisms of Ti/CFRP fiber metal laminate after adding MWCNTs to resin matrix. Composites Part B: Engineering, 171 , 254-263. https://doi.org/10.1016/j.compositesb.2019.05.0 05

Kara, M., Kirici, M. and Cagan, S. C. (2019). Effects of the number of fatigue cycles on the hoop tensile strength of glass Fiber/epoxy composite pipes. Journal of Failure Analysis and Prevention, 19(4), $1181-1186$ https://doi.org/10.1007/s11668-019-00720-z

Kaynan, O., Atescan, Y., Ozden-Yenigun, E. and Cebeci, H. (2018). Mixed Mode delamination in carbon nanotube/nanofiber interlayered composites. Composites Part B: Engineering, 154 , 186-194. https://doi.org/10.1016/j.compositesb.2018.07.0 32

Kim, M. T., Rhee, K. Y., Jung, I., Park, S. J. and Hui, D. (2014). Influence of seawater absorption on the vibration damping characteristics and fracture behaviors of basalt/CNT/epoxy multiscale composites. Composites Part B: Engineering, 63, 61-66.

https://doi.org/10.1016/j.compositesb.2014.03.0 10

Lee, M., Lee, J., Kim, J. and Lee, G. (2014). Properties of $\mathrm{B} 4 \mathrm{C}-\mathrm{PbO}-\mathrm{Al}(\mathrm{OH}) 3$-epoxy nanocomposite prepared by ultrasonic dispersion approach for high temperature neutron shields. Journal of Nuclear Materials, 445(1-3), 63-71. https://doi.org/10.1016/j.jnucmat.2013.10.051

Liu, X., Li, C., Yi, J., Prashanth, K., Chawake, N., Tao, J. and Eckert, J. (2018). Enhancing the interface bonding in carbon nanotubes reinforced $\mathrm{Al}$ matrix composites by the in situ formation of TiAl3 and TiC. Journal of Alloys and 
Compounds, 765, 98-105. https://doi.org/10.1016/j.jallcom.2018.06.170

Makowiec, M. E. and Blanchet, T. A. (2017). Improved wear resistance of nanotube-and other carbonfilled PTFE composites. Wear, 374, 77-85. https://doi.org/10.1016/j.wear.2016.12.027

Matveeva, A. Y., Lomov, S. V. and Gorbatikh, L. (2019). Debonding at the fiber/matrix interface in carbon nanotube reinforced composites: Modelling investigation. Computational Materials Science, 159, 412-419. https://doi.org/10.1016/j.commatsci.2018.10.03 1

Mittal, G., Dhand, V., Rhee, K. Y., Park, S. J., Kim, H.J. and Jung, D. H. (2015). Investigation of seawater effects on the mechanical properties of untreated and treated MMT-based glass fiber/vinylester composites. Ocean Engineering, 108 , 393-401. https://doi.org/10.1016/j.oceaneng.2015.08.019

Mousavi, M. V. and Khoramishad, H. (2019). The effect of hybridization on high-velocity impact response of carbon fiber-reinforced polymer composites using finite element modeling, Taguchi method and artificial neural network. Aerospace Science and Technology, 94, 105393. https://doi.org/10.1016/j.ast.2019.105393

Nayak, R. K. (2019). Influence of seawater aging on mechanical properties of nano- $\mathrm{Al} 2 \mathrm{O} 3$ embedded glass fiber reinforced polymer nanocomposites. Construction and Building Materials, 221, 12-19. https://doi.org/10.1016/j.conbuildmat.2019.06.0 43

Ng, K.-W., Lam, W.-H. and Pichiah, S. (2013). A review on potential applications of carbon nanotubes in marine current turbines. Renewable and Sustainable Energy Reviews, 28, 331-339. https://doi.org/10.1016/j.rser.2013.08.018

Öndürücü, A. ve Muzoğlu, M. (2019). Doğal Lif Takviyeli Kompozitlerin Burkulma Davranışına Deniz Suyunun Etkisi. Süleyman Demirel Üniversitesi Fen Bilimleri Enstitüsü Dergisi, 23(1), 30-39.

Prabhu, T. R. (2015). Effects of solid lubricants, load, and sliding speed on the tribological behavior of silica reinforced composites using design of experiments. Materials \& Design, 77, 149-160. https://doi.org/10.1016/j.matdes.2015.03.059

Rahmanian, S., Thean, K., Suraya, A., Shazed, M., Salleh, M. M. and Yusoff, H. (2013). Carbon and glass hierarchical fibers: influence of carbon nanotubes on tensile, flexural and impact properties of short fiber reinforced composites. Materials \& Design, 43, 10-16. https://doi.org/10.1016/j.matdes.2012.06.025

Tang, X., Lui, Y. H., Chen, B. and Hu, S. (2017). Functionalized carbon nanotube based hybrid electrochemical capacitors using neutral bromide redox-active electrolyte for enhancing energy density. Journal of Power Sources, 352, 118-126. https://doi.org/10.1016/j.jpowsour.2017.03.094

Taşyürek, M. (2014). Yüzey çatlaklı ve çatlaksız $\pm 55^{\circ}$ filaman sarım cnt takviyeli ctp kompozit boruların mekanik özelliklerinin ve iç basınç etkisi altındaki yorulma davranışının araştırılması. Selçuk Üniversitesi Fen Bilimleri Enstitüsü, Konya.

Taşyürek, M. and Tarakçioğlu, N. (2017). Enhanced fatigue behavior under internal pressure of CNT reinforced filament wound cracked pipes. Composites Part B: Engineering, 124, 23-30. https://doi.org/10.1016/j.compositesb.2017.05.0 50

Taşyürek, M. and Tarakçioğlu, N. (2017). Enhancing fatigue life of filament winding laminar and curved pipes containing carbon nanotubes, and their fatigue failure. Polymers and Polymer Composites, 25(2), 167-176. https://doi.org/10.1177/096739111702500207

Tsotsis, T. K., Keller, S., Lee, K., Bardis, J. and Bish, J. (2001). Aging of polymeric composite specimens for 5000 hours at elevated pressure and temperature. Composites Science and Technology, 61(1), 75-86. https://doi.org/10.1016/S0266-3538(00)00196-2

Xiao, C., Tan, Y., Wang, X., Gao, L., Wang, L. and Qi, Z. (2018). Study on interfacial and mechanical improvement of carbon fiber/epoxy composites by depositing multi-walled carbon nanotubes on fibers. Chemical Physics Letters, 703, 8-16. https://doi.org/10.1016/j.cplett.2018.05.012

Zhang, L., Wu, H., Zheng, Z., He, H., Wei, M. and Huang, X. (2019). Fabrication of graphene oxide/multi-walled carbon nanotube/urushiol formaldehyde polymer composite coatings and evaluation of their physico-mechanical properties and corrosion resistance. Progress in Organic Coatings, 127, 131-139. https://doi.org/10.1016/j.porgcoat.2018.10.026 